\title{
Research on Strategy Planning of Network Marketing Product
}

\author{
Huang Linna \\ Chongqing Business Vocational College, Chongqing, Sichuan, 400036
}

Keywords: Network Marketing, Product Strategy, Planning

\begin{abstract}
Internet marketing is selling products through the Internet platform. It is a new transaction mode emerging under the development of economic information, which provides convenience for customers of different ages and needs. With the development of technology, Internet marketing has become one of the mainstream consumption ways. Most enterprises are putting into the network marketing war in order to enhance their competitiveness. How to effectively improve their competitiveness in the network marketing war has become one of the core issues that enterprises need to solve at this stage.
\end{abstract}

\section{Introduction}

Network marketing, namely electronic marketing, is a business activity that realizes marketing purpose by means of network, communication and digital media technology. It is a manifestation of technological progress and an inevitable outcome of information society. Internet marketing came into being in 1990s. In 90s, Internet media, with new ways, methods and ideas, through a series of network marketing planning, and developing and implementing marketing activities, can more effectively facilitate the new marketing mode of transactions [1-2]. Network sales are the result of the development of network marketing to a certain stage, but it is not the final result. Therefore, network marketing itself is not equal to network sales. Network marketing is just an activity for the sale and upgrading of product image for the final purpose product. The development of online marketing has gradually matured from its embryonic stage to the present stage, and its self-organizing platform has different ways of selling, but it can't get rid of the support of internet technology [3]. Adapt to the national introduction of economic policy, the emergence of WeChat marketing, O2O marketing, Internet plus name, are two different marketing programs under the online and offline in the era of information economy to enhance their business competitiveness of many enterprises. But no matter how fast the economic and technological development is the product is still the core of the enterprise marketing. How to make the product get customers' favor in the information market? This requires enterprises to plan and improve the strategy of marketing products.

\section{The Current Situation of Network Marketing Products}

Although China's Internet starts late than the western developed countries, its development speed is fast and its penetration is strong. The most obvious manifestation is the two aspects of online social networking and online marketing. The network marketing has become one of the main channels for China's economic development, such as the recent rise of the "double eleven", "double twelve" and other large-scale promotion of commercial activities, every year in the last year to refresh record records [4]. In modern society, almost everyone can buy online, because the advantages of convenient purchase, diversified products, free time and so on promote the rapid development of network marketing.

The core of Internet marketing is still human. It is convenient and selective for customers. For enterprises, network marketing is different from marketing, providing more brand publicity for enterprises. At the same time, the network marketing enterprises lower the cost of sales, no rental store can be in front of customers own products, enhance brand competitiveness, reduce inventory pressure, the traditional marketing mode in addition to the rental store, also need to rent warehouse 
placed products, warehouse locations, also at the cost of loan fee [5]. Network marketing can alleviate this pressure, thereby reducing the production cost of enterprises, and the price of sales to customers will also decrease, so as to achieve win-win results for both sides.

At the same time, network marketing is not only a means of marketing, but also a representative of the new economy and culture. It is an innovation culture that conforms to the era of science and technology. Guiding business to enter the new world and developing new business models is a new business mode of enterprises, providing new benefits for old enterprises and providing a low threshold access for new businesses.

\section{The Main Way of Network Marketing}

There are various ways of network marketing. To plan the products of online marketing, we need to know the way of network marketing. With the development of technology, there are more and more ways of network marketing, so we can choose the right way to maximize profits [6]. The main ways of network marketing at this stage are:

1) Search engine marketing: through search engine's bidding, users can see relevant pages of search products when searching related keywords, and click to enter pages to understand product related information and understand products.

2) Email marketing: recommending a product to a required user in a subscription manner.

3) Instant messaging marketing: the promotion of products through instant messaging tools.

4) Viral marketing: the viral marketing mode comes from the network marketing, which is based on the principle of word of mouth, which is a low cost marketing method between users.

5) Micro-blog marketing: one of the main marketing methods at this stage, because micro-blog has a wide audience, marketing through the public and promotion of the micro-blog platform.

6) WeChat marketing: through the WeChat platform for point to point marketing promotion.

7) Soft text marketing: one of the most effective ways of marketing, soft text is rich and interesting more easy to attract consumers to understand the product.

8) O2O stereo marketing: one of the most perfect marketing stage, integrated marketing media depth online and offline based on cooperation, for the different needs of the audience can choose different channels of dissemination of product information, a diversified way of integration, three-dimensional marketing network coverage of the masses.

9) Self-media marketing: since the media also known as "citizen media" or "personal media", since the media platform involves many, from the media flexible marketing mode widely accepted by consumers.

10) Video marketing: the product is displayed in front of the public through creative video, which is easily accepted by the majority of consumers.

\section{Planning Method}

\subsection{Clear product positioning}

If you want to become evergreen, the positioning of products is very important. Different products sell for different audiences. Only by defining the location of products can we choose the audience to promote sales and minimize the cost and maximize profits. If the enterprise through the Tmall platform flagship store, in the classification of products is a location, such as the positioning of the garment can be divided into men's and women's clothing, children's clothing, in the old equipment, for the purchase of the crowd is different, different product positioning, which directly affect the product sales [7-8]. The biggest difference between network marketing and marketing is that customers can't directly contact products. They can only check whether or not they meet their own requirements by displaying pictures and parts of information, so positioning products is the first step in planning. In the planning of product strategy should pay attention to this point, such as is the version of the type of women's women are most concerned about is a good, quality is good enough, whether for their own sales network in size, customers can not directly contact with the 
product can try to see if I fit the body [9]. Therefore, businesses should list detailed information such as product name, size and so on, enabling consumers to grasp important information quickly and quickly, and eliminate doubts when buying products pages, and quickly achieve transactions.

\subsection{Guarantee the quality of the product}

Because of the digitalization of information, customers are restricted by space when they buy products. The quality of products will lead consumers to be deceived by the beautification of network information, which makes consumers hesitate when buying products. At the present stage of the online shopping platform set up in praise, comment and comment on the difference of three standard, the product has been purchased by a consumer evaluation of products, businesses to display of goods to network sales through the relevant platform in network marketing, so whether it is the quality of merchants or consumers pay great attention to the product. The products directly affect the quality of the product sales. For example, businesses through Jingdong platform sales of seasonal fruits, consumers certainly hope to is to eat fresh fruit, but apart from the quality of the fruits in addition to meet delivery distance on a series of problems, such as whether the package can ensure that fresh fruit in a period of time, and in the delivery of distance cost this time, in order to deal with some contradictions, Jingdong planned a Jingdong owned cold chain distribution scheme, the maximum guarantee of product quality problems [10].

\subsection{Product branding}

Although marketing and network marketing rely on different platforms, but in essence, they are the same, they are all for sale products, so in online marketing, the producers of products are also important as brands and word-of-mouth of dealers. One is as mentioned above, the network marketing is the virtual digital information, consumers can also touched the real product, do not know the quality of the product; on the other hand it is because in the network marketing in the commodity variety, consumers face more choices, it will pay more attention to choose products brand. For example, when consumers choose cosmetics or skin care products, they will pay more attention to brand selection, because brand names have good reputation and quality assurance, and there will be after-sales guarantee when buying [11]. As we all know, the characteristics of skin care products and cosmetics are suitable for personal skin. When consumers choose, consumers will pay more attention to this. Some sensitive skin consumers pay more attention to the suitability of products when they choose skin care products and cosmetics. In online marketing, consumers can't ensure that products are suitable for their skin by trial, so they will choose according to their brand characteristics. Therefore, we should brand products and word-of-mouth products in this product's online marketing strategy.

\subsection{Product packaging logistics chain}

Internet marketing is faced with consumers all over the country and even the whole world. Consumers will start waiting for businesses to deliver goods and deliver goods after they decide to buy them. The speed of logistics will also affect consumers' purchase experience. At present, many businesses are using the cooperation with the courier company to solve the problem of product delivery, and logistics companies face such a huge flow of most of the fast sorting without any guarantee of sorting, transport, which requires businesses in the process for some vulnerable products in the packaging must be carefully, in order to avoid when the product is delivered to consumers has been damaged, affecting the consumer experience. For example, consumers monumental mugs and other natural products in the purchase to receive unscathed, businesses need to plan a detailed plan on how to packaging [12]. After successfully selling products, we must ensure that products are delivered to consumers in good condition, and they can be packaged by means of multiple protection such as foams, waste newspapers, and the most secure and reliable way to transport products between cooperative logistics companies.

To sum up, in the online marketing product strategy, we should pay attention to the five aspects of product positioning, including audience, product quality, product branding and product packaging logistics chain. A good planning plan can make an excellent network marketing product 
strategy. Excellent network marketing product strategy can contribute to the economic development of enterprises and improve product sales.

\section{Planning Type}

The way of network marketing planning is also divided into various planning types. Different planning types aim at different directions of development. Before formulating network marketing product strategy, we should formulate development direction and formulate different planning types.

1) Entrepreneurial planning: the low cost of Internet marketing and the wide audience market are mostly favored by entrepreneurs. This also requires that we should start from the perspective of planning network marketing product strategy, with detailed contents to details. The specific content should be from the starting, prediction, pre implementation to the specific implementation of the hidden risk factors, and so on.

2) Improved planning: the development of the era is fast. The network marketing strategy should also keep pace with the times. We should consider the audience's face when we update the content, and consider all kinds of factors during the planning process, such as the fierce competition of the competitors, and how to stand out.

3) Aided planning: on the basis of existing ways, we should strengthen the efforts of network marketing in various ways, achieve better marketing results, achieve the plan of improving product sales and product brand reputation, and optimize the network marketing strategy.

4) Gain planning: in order to improve the performance of the enterprise, optimize the network marketing plan to make a new gain planning scheme and improve the competitiveness of the enterprise.

5) Service oriented planning: planning service network marketing strategy, directly contacting with consumers, enabling consumers to get product related information for the first time, and achieve the purpose of network marketing products.

\section{Conclusions}

Internet marketing is the inevitable outcome of the development of Internet technology, and also the specific manifestation of economic globalization. Excellent planning methods can help enterprises to enhance their competitiveness in business competition, and the strategy of network marketing requires detailed planning. The product positioning, audience, quality, brand and packaging logistics is summarized, the network marketing channels through the Internet, and now the stage of network marketing in the continuously reform and innovation, from search engine marketing to $\mathrm{O} 2 \mathrm{O}$ stereo marketing, now since the media marketing and other diversified marketing are brought by information technology, enterprises in order to enhance their business competitiveness also need to pay great efforts be rewarded. At the same time, when we plan the product network marketing strategy, we should clarify the marketing purpose, select the appropriate marketing way, and display the product information in front of consumers in detail, so as to maximize the effectiveness of network marketing.

\section{References}

[1] Liu Y, Zhang N. Research on the Pricing Strategy of Hotel Room Based on Network Marketing [J]. Prices Monthly, 2014, 556-562:3384-3387.

[2] Zhu R, Yang L. Strategy Research on Car Brand Network Marketing Based on SNS Platform[J]. Journal of Chongqing Technology \& Business University, 2013.

[3] Ling S. The Research of Influence Factors Model of Enterprise Network Marketing Ethics Level in Economic Transition Period [J]. Science \& Technology Management Research, 2014.

[4] Chen X, University H. Study on the development strategy of Henan Province agricultural 
product network marketing [J]. Journal of Jiamusi Education Institute, 2014.

[5] Du W. Product Network Marketing Strategy and Design Analysis[C]// International Conference on Education Technology and Social Science. 2014.

[6] Xiao-Fang L I. RESEARCH ON PERFORMANCE EVALUATION OF ENTERPRISE NETWORK MARKETING IN POST-CRISIS ERA [J]. Journal of Nanyang Institute of Technology, 2014.

[7] Chen Y Z, Sun C C. Network Marketing Strategy of Home Decoration Wire Based on SWOT Analysis Method [J]. Value Engineering, 2015.

[8] Li X, Zhang J. Research on Evaluation Indicator System and Methods of Food Network Marketing Performance [J]. Advance Journal of Food Science \& Technology, 2015, 7(10):810-814.

[9] Xue W, Pei Y, Li D. Research on Network Marketing Performance Evaluation Based on GIOWA Operator [M]// LISS 2014. Springer Berlin Heidelberg, 2015.

[10] Wen Y. Research on the Innovation Strategy of Network Marketing in Micro Era [J]. Journal of Hubei Correspondence University, 2016.

[11] Rong-Rong Q I, Wen X S, University X. Research on Network Marketing Strategy of Agricultural Products(nuts) in Shaanxi Province[J]. Computer Knowledge \& Technology, 2015.

[12] Jiang Y. The Study and Research on Chinese Sports Network Marketing Strategy [M]// Ubiquitous Computing Application and Wireless Sensor. Springer Netherlands, 2015:519-528. 